

\title{
PERTUMBUHAN EKONOMI, TINGKAT PENGANGGURAN, DAN KONSUMSI, DALAM BINGKAI KESEJAHTERAAN MASYARAKAT
}

\author{
Syamsul Arifin, M.Pd.
}

Prof. Dr. Yoyok Soesatyo, SH,MM., Ph.D.

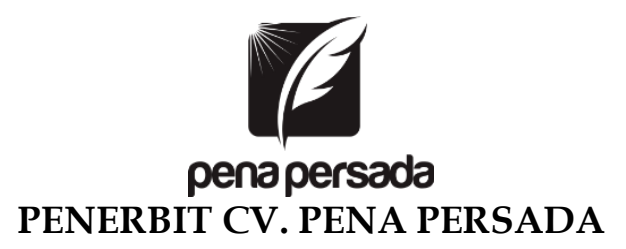




\title{
PERTUMBUHAN EKONOMI, TINGKAT PENGANGGURAN, DAN KONSUMSI, DALAM BINGKAI KESEJAHTERAAN \\ MASYARAKAT
}

\author{
Penulis : \\ Syamsul Arifin, M.Pd. \\ Prof. Dr. Yoyok Soesatyo, SH., MM,Ph.D. \\ Editor : \\ Wiwit Kurniawan \\ ISBN : 978-623-6688-88-5 \\ Design Cover : \\ Retnani Nur Briliant \\ Layout : \\ Nisa Falahia \\ Penerbit CV. Pena Persada \\ Redaksi : \\ Jl. Gerilya No. 292 Purwokerto Selatan, Kab. Banyumas \\ Jawa Tengah \\ Email : penerbit.penapersada@gmail.com \\ Website : penapersada.com \\ Phone : (0281) 7771388
}

\section{Anggota IKAPI}

All right reserved

Cetakan pertama : 2020

Hak cipta dilindungi oleh undang-undang. Dilarang memperbanyak karya tulis ini dalam bentuk apapun tanpa izin penerbit. 


\section{KATA PENGANTAR}

Syukur Alhamdulillah penulis panjatkan kehadirat ALLAH SWT yang telah memberikan perlindungan dan petunjuk-Nya, sehingga penulis dapat menyelesaikan buku dengan judul "Pertumbuhan Ekonomi, Tingkat Pengangguran, dan Konsumsi, Dalam Bingkai Kesejahteraan Masyarakat"

Selama penyusunan buku ini, penulis banyak dibantu berbagai pihak, baik secara langsung maupun tidak langsung, yang telah membantu dan memberikan berbagai macam kritik dan masukan bagi penulis. Buku ini bertujuan untuk menganalisis pengaruh pertumbuhan ekonomi terhadap kesejahteraan masyarakat di Kabupaten Sampang. Menganalisis pengaruh tingkat pengangguran terhadap kesejahteraan masyarakat di Kabupaten Sampang. Menganalisis pengaruh konsumsi terhadap kesejahteraan masyarakat di Kabupaten Sampang. Menganalisis pengaruh pertumbuhan ekonomi, tingkat pengangguran dan konsumsi terhadap kesejahteraan masyarakat Kabupaten Sampang.

Penulis sadar bahwa buku ini masih memiliki banyak kekurangan. Oleh karena itu, kritik dan saran kami harapkan dari semua pihak pembaca untuk membangun buku ini menjadi lebih baik.

Surabaya, Juni 2018

Penulis 


\section{DAFTAR ISI}

KATA PENGANTAR ....................................................... iii

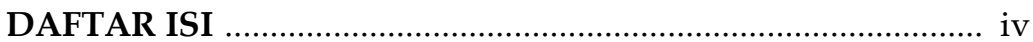

BAB I PENDAHULUAN ................................................. 1

A. Kesejahteraan Masyarakat........................................ 1

B. Tingkat Kesejahteraan ............................................... 3

BAB II PERTUMBUHAN EKONOMI..................................... 9

A. Teori Pertumbuhan Adam Smith .............................. 10

B. Teori Pertumbuhan David Ricardo ............................ 11

C. Teori Pertumbuhan dari Thomas Robert Malthus ........ 12

D. Teori pertumbuhan Marx ............................................. 12

E. Teori Pertumbuhan Neo Keynesian ........................... 14

F. Model Pertumbuhan W.W. Rostow ............................ 15

G. Model Pertumbuhan Solow ........................................ 16

H. Hubungan pertumbuhan ekonomi dengan Kesejahteraan.................................................................. 20

BAB III PENGANGGURAN............................................. 22

A. Teori Pengangguran................................................. 22

B. Dampak Pengangguran............................................ 27

C. Hubungan Pengangguran dengan Kesejahteraan. ....... 29

BAB IV KONSUMSI........................................................... 31

A. Pengertian Konsumsi................................................. 31

B. Pendapatan dan Konsumsi ...................................... 33

C. Hubungan Konsumsi dengan Kesejahteraan .............. 35

BAB V KESEJAHTERAAN .................................................. 37

A. Definisi Kesejahteran ............................................... 37

B. Indikator Kesejahteraan Masyarakat........................... 40

C. Hubungan Pertumbuhan Ekonomi, Pengangguran, dan Konsumsi dengan Kesejahteraan ........................ 42

BAB VI GAMBARAN PEREKONOMIAN DAN TINGKAT KESEJAHTERAAN DAERAH........................................... 44

A. Gambaran Umum Kota Sampang .............................. 44

B. Perkembangan Pertumbuhan Ekonomi Kabupaten Sampang ................................................................ 45

C. Tingkat Pengangguran di Kabuapten Sampang .......... 50

D. Tingkat Konsumsi di Kabupaten Sampang ................. 51 
E. Tingkat Indeks Pembangunan Manusia di Kabupaten Sampang tahun 2006-2015.

BAB VII FAKTOR-FAKTOR YANG MEMPENGARUHI TINGKAT KESEJAHTERAAN MASYARAKAT

A. Pengaruh Pertumbuhan Ekonomi terhadap Kesejahteraan Masyarakat Kabupaten Sampang 55

B. Pengaruh Tingkat Pengangguran terhadap Kesejahteraan Masyrakat Kabupaten Sampang.. 58

C. Pengaruh Tingkat Konsumsi terhadap Kesejahteraan Masyarakat Kabupaten Sampang.

D. Pengaruh Pertumbuhan Ekonomi, Tingkat Pengangguran dan Konsumsi terhadap Kesejahteraan Masyarakat 61

BAB VIII PENUTUP 65

DAFTAR PUSTAKA 66 
PERTUMBUHAN EKONOMI, TINGKAT PENGANGGURAN, DAN KONSUMSI, DALAM BINGKAI KESEJAHTERAAN MASYARAKAT 


\section{BAB I \\ PENDAHULUAN}

\section{A. Kesejahteraan Masyarakat}

Pembangunan nasional merupakan suatu upaya untuk menciptakan masyarakat yang adil, makmur, berdaya saing, maju dan sejahtera. Berbagai kegiatan pembangunan telah dilaksanakan oleh pemerintah Indonesia dalam mengatur perekonomian sebagai upaya menjaga stabilitas perekonomian. Salah satu indikator utama keberhasilan pembangunan adalah kesejahteraan masyarakat Kesejahteraan merupakan salah satu aspek yang cukup penting untuk menjaga dan membina terjadinya stabilitas sosial dan ekonomi karena kondisi ini diperlukan untuk meminimalkan terjadinya kecemburuan sosial dalam masyrakat.

Upaya yang di lakukan pemerintah terkait dengan menjaga stabilitas perekonomian dalam meningkatkan kesejahteraan masyarakat melalui Human Development Index (HDI) Mankiw (2006). Laporan pembangunan manusia baik di tingkat global, nasional maupun daerah bahwa pembangunan manusia yang berpusat pada manusia sebagai tujuan akhir dari pembangunan, bukan sebagai bagian pembangunan. (BPS, 2015).

Tingkat kesejahteraan masyarakat kota dan desa adalah sama dimana standar kreteria kesejahteraan masyarakat menurut Badan Pusat Statistik (BPS) adalah pendapatan, konsumsi, keadaan tempat tinggal, fasilitas tempat tinggal, kesehatan anggota keluarga, kemudahan mendapatkan pelayanan kesehatan, kemudahan memasukkan anak ke jenjang pendidikan, dan kemudahan fasilitasi transportasi.

Sampang merupakan salah satu Kabupaten yang terletak di pulau madura yang memiliki potensi kekayaan sumber daya alam yang cukup besar, seperti kekayaan laut, garam dan pertambangan minyak namun pada data BPS (2016) 
di ketahui bahwa Kabupaten Sampang merupakan Kabupaten dengan tingkat kemiskinan tertinggi di Jawa Timur yakni menempati urutan pertama dengan jumlah presentase kemiskinan tertinggi di Provinsi Jawa Timur, yaitu sebesar 27,9\% dari total jumlah penduduknya. Urutan kedua dan ketiga diikuti Kabupaten Bangkalan dan Kabupaten Probolinggo masingmasing sebesar $24,7 \%$ dan $22,2 \%$. Sedangkan daerah yang memiliki jumlah presentase kemiskinan terendah adalah Kota Batu sebesar $4,47 \%$ dari total jumlah penduduknya. Hal ini menunjukkan tingginya tingkat kemiskinan di Kabupaten Sampang berdampak pada rendahnya kesejahteraan masyarakat di Kabupaten Sampang. Kesejahteraan masyarakat di Kabupaten Sampang bisa dilihat dari indek pembangunan manusia dari tahun ketahun, berikut adalah tabel IPM di Kabupaten Sampang tahun 2012-2015.

Tabel 1.1

Nilai Indeks Pembangunan Manusia

\begin{tabular}{cc}
\hline Tahun & Indeks Pembangunan Manusia \\
\hline 2012 & 55.78 \\
\hline 2013 & 56.45 \\
\hline 2014 & 56.98 \\
\hline 2015 & 58.18 \\
\hline
\end{tabular}

Sumber: BPS Provinsi jawa timur, (2016)

Hal ini dapat di lihat dari tabel 1.1 bahwasannya indeks pembangunan manusia (IPM) dari tahun 2012-2015 mengalami peningkatan dari tahun ke tahunnya tetapi tidak cukup besar, dari tahun 2012 ke tahun 2013 meningkat sebesar o,67\% sedangkan pada tahun berikutnya hanya meningkat sebesar 0,53\% dan pada tahun 2014 ke tahun 2015 meningkat sebesar $1,2 \%$. Menurut BPS (2015) Indek pembangunan manusia memiliki kategori sebagai berikut Untuk melihat capaian IPM antar wilayah dapat dilihat melalui pengelompokkan IPM ke dalam beberapa kategori, yaitu: IPM < 60 : IPM rendah 60-70 : IPM sedang 70- 80 : IPM tinggi IPM > 80 : IPM sangat tinggi. Melihat dari kategori tersebut Kabupaten Sampang masih 
tergolong dengan IPM rendah, Meskipun indek pembangunan manusia di Kabupaten Sampang dari tahun ketahunnya mengalami peningkatan, namun kesejahteraan di Kabupaten Sampang masih terbilang rendah.

\section{B. Tingkat Kesejahteraan}

Peningkatan kesejahteraan juga dapat dipengaruhi oleh pertumbuhan ekonomi Mirza (2011). Sedangkan menurut Todaro \& Smith (2000) menyatakan bahwa semakin tinggi pertumbuhan ekonomi suatu wilayah menandakan semakin baik kegiatan ekonominya, kegiatan ekonomi diperoleh dari pertumbuhan PDRB (produk domestik regional bruto) PDRB merupakan nilai tambah yang dihasilkan oleh seluruh unit usaha dalam suatu daerah tertentu. Pada analisis ini menggunakan data PDRB menurut lapangan usaha, untuk mengetahui sektor-sektor lapangan usaha mana yang memiliki peranan penting terhadap kesejahteraan masyarakat.

PDRB di Kabupaten Sampang menurut sektor lapangan usaha pada tahun 2011-2015 dapat di lihat dalam tabel sebagai berikut:

Tabel 1.2

PDRB Kabupaten Sampang Menurut Sektor Lapangan

\begin{tabular}{cc}
\multicolumn{2}{c}{ Usaha (\%) } \\
\hline Tahun & PDRB Sekto Lapangan Usaha \\
\hline 2011 & 2.50 \\
\hline 2012 & 5.77 \\
\hline 2013 & 6.53 \\
\hline 2014 & 0.08 \\
\hline 2015 & 2.08 \\
\hline
\end{tabular}

Sumber: BPS Provinsi Jawa Timur (2016)

Bila di lihat data pada tabel 1.2 PDRB menurut sektor lapangan usaha di Kabupaten Sampang pada tahun 2011 sebesar $2.50 \%$. Sedangkan pada tahun tahun 2012 meningkat sebesar 5.77\% ,di tahun 2013 meningkat sebesar 6.53\% di tahun 2014 menurun yakni sebesar 0,08 dan pada tahun 2015 PDRB di Kabupaten Sampang meningkat sebesar 2.08. Dari penjabaran 
tersebut terlihat bahwasannya PDRB Kabupaten Sampang menurut sektor lapangan usaha dari tahun 2011-2013 selalu mengalami kenaikan, dengan meningkatnya PDRB tersebut maka dapat dikatakan bahwa kesejahteraan masyarakat di Kabupaten Sampang terus mengalami kenaikan dari tahun ke tahunnya. Namun fenomena yang terjadi indeks pembangunan manusia di Kabupaten Sampang dari tahun 2011-2015 masih tergolong kategori rendah.

Selain hal di atas menurunnya kesejahteraan juga dipengaruhi oleh pengangguran wirawan (2015). Karena pengangguran merupakan salah satu sumber masalah ekonomi, ketidakseimbangan jumlah angkatan kerja dengan tersedianya lapangan kerja menjadi penyebab terjadinya pengangguran, Tingginya angka pengangguran di suatu Negara dan suatu daerah akan berdampak pada perekonomian Negara atau daerah tersebut. Salah satu dampaknya adalah timbulnya dan meningkatnya tindakan kriminal karena orang membutuhkan penghasilan untuk memenuhi kebutuhan sehari-hari, sementara pengangguran tentu tidak memiliki penghasilan, selain itu memacu meningkatnya jumlah anak jalanan, pengemis, dan gelandangan yang berkeliaran di jalanan Memacu sikap perlawanan dari masyarakat misalnya demonstrasi menuntut keadilan, dan mengakibatkan masyarakat tidak mampu mengoptimalkan kesejahteraan hidupnya. Tingkat pengangguran masyarakat di Kabupaten Sampang di gambarkan pada tabel berikut.

Tabel 1.3

Tingkat pengangguran di Kabupaten Sampang (\%) Tahun Tingkat Pengangguran

\begin{tabular}{ll}
\hline 2011 & 3,91 \\
\hline 2012 & 1,78 \\
\hline 2013 & 4,74 \\
\hline 2014 & 2,22 \\
\hline 2015 & 2,51
\end{tabular}

Sumber: BPS Provinsi Jawa Timur (2016) 
Naiknya pertumbuhan ekonomi di Kabupaten Sampang seharusnya berdampak dengan terus menurunnya tingkat Pengangguran yang ada di Kabupaten Sampang. Akan tetapi fenomena yang ada, menurut data pada tabel 1.3 menjelaskan bahwa tingkat pengangguran di Kabupaten Sampang memiliki siklus yang naik turun, yang mana hal tersebut menggambarkan bahwasanya masyarakat di Kabupaten Sampang masih banyak yang menganggur, pada tahun 2015 pengangguran di Kabupaten Sampang sebesar 2,51 naik dari tahun sebelumnya yakni 2,22, adanya kenaikan pengangguran ini disebabkan dengan minimnya lapangan pekerjaan, serta banyaknya usaha yang mengalami kegagalan bari dari sektor pertanian ataupun sektor usaha, yang mengakibatkan masyarakat di Kabupaten Sampang berhenti bekerja, dan di PHK, dengan adanya kegagalan usaha dan sedikitnya lapangan pekerjaan diKabupaten Sampang tersebut dapat mengurangi tingkat kesejahteraan masyarakat di Kabupaten Sampang.

Pengangguran di Kabupaten Sampang masih tergolong rendah dibandingkan dengan Kabupaten lain di Jawa Timur (BPS,2015). Fenomena ini sesuai dengan pernyataan Sukirno (2012). bahwa efek dari pengangguran adalah dapat mengurangi tingkat kemakmuran. Semakin turunnya kemakmuran masyarakat karena menganggur tentunya akan meningkatkan peluang mereka terjebak dalam kemiskinan karena tidak memiliki pendapatan.

Selain itu kesejahteraan juga di pengaruhi oleh konsumsi masyarakat, yang mana hal tersebut berkaitan erat dengan pendapatan, Menurut keynes dari ekonomi klasik menyatakan bahwa pengeluaran konsumsi tergantung dari pendapatan, semakin tinggi pendapatan seseorang maka semakin tinggi pula konsumsi yang di keluarkan. Dan adanya pendapatan yang tinggi masyrakat mampu memenuhi kebutuhanya dan hal itu berarti juga meningkatkan kesejahteraan. Sebagaimana penelitian oleh Wagle et al. (2006). Menyatakan bahwa pendapatan dan konsumsi merupakan variabel sederhana yang menentukan kesejahteraan, karena baik secara individu 
maupun rumah tangga dapat digunakan untuk mencapai kesejahteraan manusia, Pendapatan dan konsumsi cenderung sangat berhubungan satu sama lain karena konsumsi berasal dari pendapatan dan pendapatan sangat penting untuk konsumsi. Hal tersebut sesuai dengan penelitian yang dilakukan oleh Gan (2013) yang menyatakan bahwa konsumsi merupakan kegiatan menggunakan barang dan jasa untuk mengurangi atau menghabiskan nilai guna suatu barang dengan tujuan memenuhi kebutuhan hidup setiap hari, yang mana konsumsi yang dilakukan tersebut menunjukkan kesejahteraan seseorang.

Dalam indikator kesejahteraan BPS (Badan Pusat Statistik), konsumsi merupakan salah satu indikator dari kesejahteraan masyarakat, dimana konsumsi masyarakat di lihat dari konsumsi makanan dan non makanan. Apabila tingkat konsumsi untuk non makanan lebih tinggi dari konsumsi makanan maka dapat dikatakan bahwa kesejahteraan masyarakat daerah tersebut meningkat. Konsumsi masyarakat Kabupaten Sampang di gambarkan pada tabel berikut.

Tabel 1.4

Tingkat Konsumsi Masyarakat Kabupaten Sampang.

\begin{tabular}{|c|c|c|c|c|c|}
\hline Kelompok konsumsi & 2010 & 2011 & 2012 & 2013 & 2014 \\
\hline $\begin{array}{l}\text { a. Makanan, } \\
\text { minuman, rokok }\end{array}$ & 48.77 & 48.24 & 48.04 & 47.31 & 46.65 \\
\hline $\begin{array}{l}\text { b. Pakaian dan alas } \\
\text { kaki }\end{array}$ & 3.70 & 3.77 & 3.72 & 3.74 & 3.75 \\
\hline $\begin{array}{l}\text { c. Perumahan, } \\
\text { perkakas } \\
\text { perlengkapan dan } \\
\text { penyelengaraan } \\
\text { rumah }\end{array}$ & 11.42 & 11.42 & 11.38 & 11.78 & 11.58 \\
\hline $\begin{array}{l}\text { d. Kesehatan dan } \\
\text { tingkat pengang- } \\
\text { guran }\end{array}$ & 4.75 & 4.92 & 5.03 & 5.10 & 5.09 \\
\hline
\end{tabular}


e. Transportasi,

$\begin{array}{lllll}16.19 & 16.15 & 16.33 & 16.68 & 17.47\end{array}$

komunikasi,

rekreasi, dan

budaya.

$\begin{array}{lllllll}\text { f. } & \text { Hotel dan resroran. } & 9.70 & 9.69 & 9.65 & 9.56 & 9.82\end{array}$

$\begin{array}{llllll}\text { g. Lainnya. } & 5.47 & 5.81 & 5.86 & 5.83 & 5.65\end{array}$

$\begin{array}{llllll}\text { Total konsumsi } & 100 \% & 100 \% & 100 \% & 100 \% & 100 \%\end{array}$

Sumber: BPS Provinsi jawa timur (2016)

Dari tabel 1.4 dapat di simpulkan bahwa secara ratarata dari tahun 2010 s.d 2014, nampak pada struktur konsumsi akhir rumah tangga Kabupaten Sampang, bahwa konsumsi bukan makanan lebih tinggi dibandingkan konsumsi makanan. Proporsi pengeluaran untuk makanan cenderung masih berada pada kisaran yang sama. Proporsi untuk makanan pada masing-masing tahun mencapai 48,77 persen (2010) ; 48,24 persen (2011) ; 48,04 persen (2012) ; 47,31 persen (2013) ; dan 46,65 persen (2014). Sementara proporsi pengeluaran bukan makanan menunjukkan bahwa konsumsi akhir rumah tangga Kabupaten Sampang yang tertinggi adalah sub komponen transportasi, komunikasi, rekreasi dan budaya yang berada pada kisaran 16 sampai 17 persen dari total konsumi akhir rumah tangga. Proporsi konsumsi rumah tangga atas makanan dan non makanan yang masih berimbang. Menunjukkan bahwa sebagian besar pengeluaran rumah tangga digunakan untuk memenuhi kebutuhan pokoknya (konsumsi makanan). Sungguh pun demikian, pengeluaran untuk kebutuhan nonmakanan menjadi semakin penting sebagai akibat dari perubahan dan pengaruh tatanan ekonomi sosial dalam masyarakat. Pengeluaran tersebut di antaranya meliputi biaya untuk tingkat pendidikan, pembelian alat dan perlengkapan elektronik pembelian alat transportasi, jasa komunikasi, jasa transportasi, jasa kesehatan, perjalanan wisata, restoran, sewa bangunan tempat tinggal dan jasa hiburan. 
Dari uraian tersebut maka penulis tertarik ingin menulis buku tentang "Pertumbuhan Ekonomi, Tingkat pengangguran dan Konsumsi Terhadap Kesejahteraan masyarakat". 